\title{
Olfactory and Gustatory Dysfunction in Children with COVID-19.
}

\author{
Marta Bernaola ${ }^{1}$, Irene Bartha ${ }^{1}$, Gustavo Adolfo Lopez-Araujo ${ }^{1}$, Carmelo Escudero ${ }^{1}$, Pablo \\ Rodriguez del Rio ${ }^{1}$, Cristina Morales-Cabeza ${ }^{1}$, Raphaëlle Bazire ${ }^{1}$, and María Dolores \\ Ibáñez ${ }^{1}$ \\ ${ }^{1}$ Hospital Infantil Universitario Niño Jesús
}

September 28, 2020

\begin{abstract}
Olfactory and gustatory dysfunctions (OGD) have been reported as relevant symptoms that may predict presence of coronavirus disease 2019 (COVID-19) in adults, associated with mild or moderate disease1, 2, 3. However, published data on OGD in children are scant, likely due to several factors specific to the pediatric population such as a lower incidence of infection, the tendency of COVID-19 to be asymptomatic4, 5, and the difficulty of studying childhood OGD with objective methods. Two case reports have been published to date: one with 3 adolescents6, and the other describing a 17-year-old girl with beta-thalassemia who presented total loss of smell and taste for 8 days7. Current data on the prevalence of OGD are based on only 2 small cohorts of COVID-19-positive children8, 9. In a related study, Mannheim et al.10 describe that 19 (30\%) of 64 infected children (0-17 years old) presented nasal congestion, rhinorrhea, and total loss of smell, though providing no data on the exact number of patients with olfactory dysfunction exclusively.
\end{abstract}

\section{Hosted file}

2.pdf available at https://authorea.com/users/361143/articles/482875-olfactory-andgustatory-dysfunction-in-children-with-covid-19

\section{Hosted file}

3.pdf available at https://authorea.com/users/361143/articles/482875-olfactory-andgustatory-dysfunction-in-children-with-covid-19

\section{Hosted file}

Figure 1.pdf available at https://authorea.com/users/361143/articles/482875-olfactory-andgustatory-dysfunction-in-children-with-covid-19

\section{Hosted file}

Table 1.pdf available at https://authorea.com/users/361143/articles/482875-olfactory-andgustatory-dysfunction-in-children-with-covid-19

\section{Hosted file}

Table 2.pdf available at https://authorea.com/users/361143/articles/482875-olfactory-andgustatory-dysfunction-in-children-with-covid-19 